\title{
Congenital aplasia of the heel pad
}

\author{
Karthikeyan P lyengar 다, ' Gopalkrishna G Verma (10 , ${ }^{2}$ Saksham Mittal, ${ }_{1}^{3}$ \\ Vijay Kumar Jain ${ }^{3}$
}

${ }^{1}$ Trauma and Orthopaedics, Southport and Ormskirk Hospital NHS Trust, Southport, UK

${ }^{2}$ Trauma and Orthopaedics, Manchester University NHS Foundation Trust, Manchester, UK

${ }^{3}$ Department of Orthopaedics, Atal Bihari Vajpayee Institute of Medical Sciences, Dr Ram Manohar Lohia Hospital, New Delhi, Delhi, India

\section{Correspondence to Karthikeyan P lyengar: kiyengar@nhs.net}

Accepted 12 October 2020

\section{DESCRIPTION}

Congenital aplasia of the heel pad is a descriptive term for a rare anomaly of the foot noted at birth or within the first few years of life. The normal heel pad is a specialised structure that lies between the os calcis and plantar skin consisting of microchambers and macrochambers of adipose tissue divided by intricate fibroelastic septations.

The os calcis is the first tarsal bone to ossify between 20 and 24 weeks after birth, and maturation of the heel pad continues through adolescence. Thickness of the heel pad averages $18 \mathrm{~mm}$, ranging from $14.4 \mathrm{~mm}$ to $24.5 \mathrm{~mm}$. The foot is an organ of support and locomotion, with the heel pad acting as a shock absorber designed to alleviate compression and shear forces on the os calcis which it envelopes. ${ }^{1}$ On heel strike, 2.5 times the body weight goes through the heel pad during each step in the gait cycle. ${ }^{2}$ Absence of heel pad exposes the sole of the heel to undue pressure from os calcis and can lead to the development of callosities and intractable keratoma formation.

We present some interesting clinical photographs and plain radiographs of a 14-year-old boy who attended clinic with a painful limp and cosmetic deformity of his left foot since birth (figures 1 and 2). There was no history of high energy injury to the foot. Parents did not know of any other family members with similar features. The patient walked with a slight antalgic gait with minimal limb length discrepancy. His left heel had multiple callosities and was clearly smaller than the normal right foot. The os calcis could be felt immediately underneath the thickened skin and there was an absence of a normal soft heel pad. The hind foot was in varus with pes planus deformity. The ankle, subtalar and
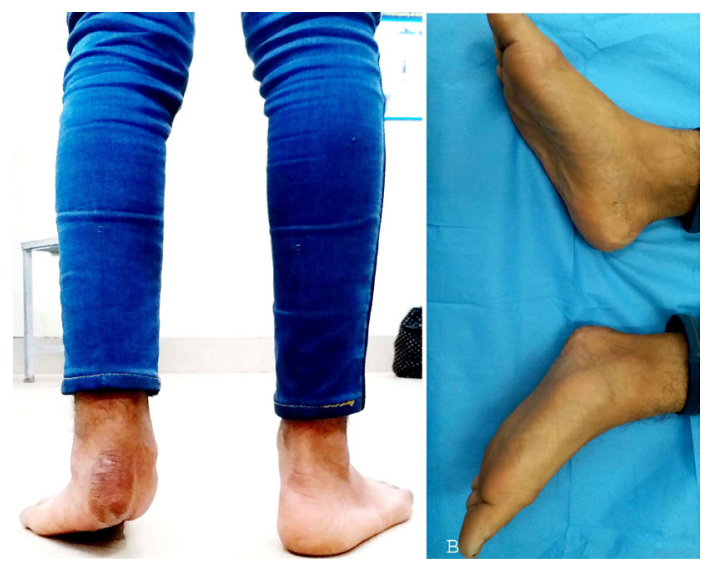

Figure 1 A: Standing clinical photographs of the patient with aplastic left heel. B: in supine position showing aplastic left heal.

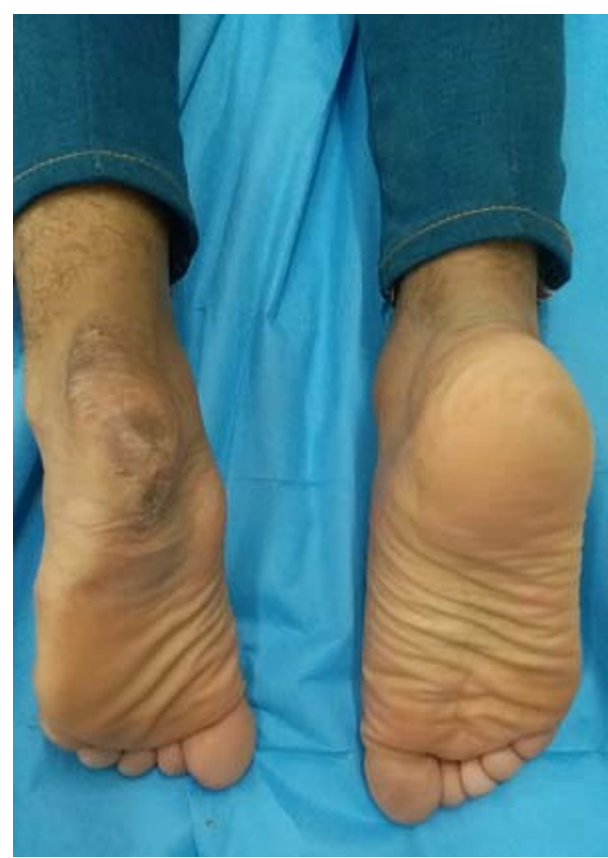

Figure 2 Clinical photograph of both heels with the patient in prone position.

midfoot joint range of movements were equal to the right side. It was felt that the deformity of his foot was secondary to his adapted gait. Neurological examination was normal, with no sensory or motor deficit.

Foot and axial radiographs of both calcanei show a smaller size of the left os calcis which was underdeveloped with an altered shape. The soft tissue heel shadow was absent (figures 3 and 4).

We believe such a presentation has not been reported before. This anomaly can be confused with congenital vertical talus or congenital talo equino varus (clubfoot) but these have classical features and thus can be ruled out with clinical examination and appropriate radiography. ${ }^{3}$

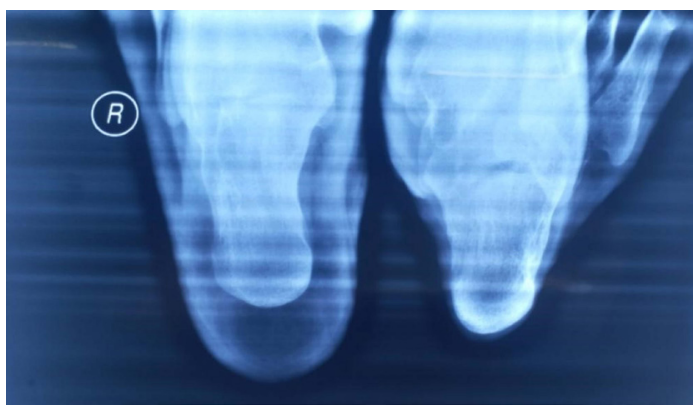

Figure 3 Plain radiograph of the os calcanei showing an absent left heel pad. 


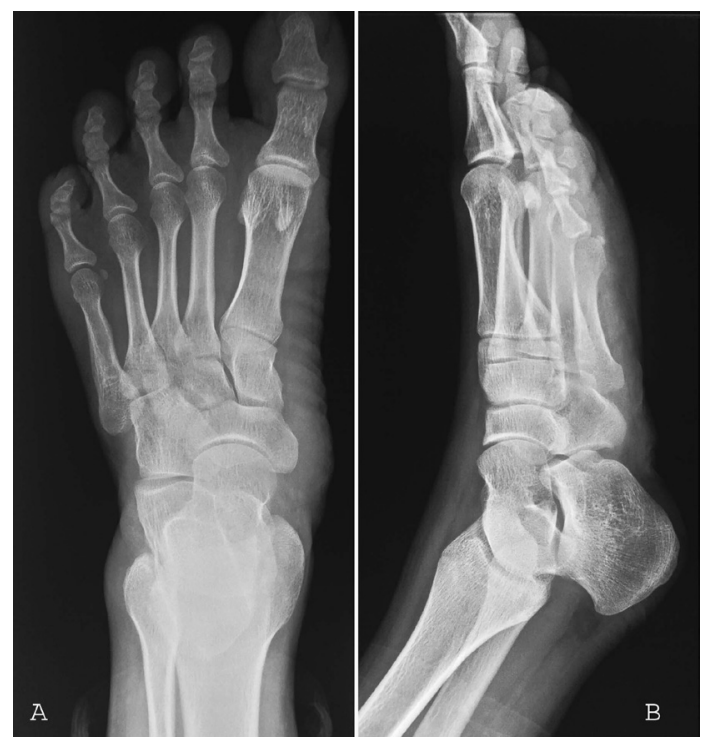

Figure 4 Radiographs of the foot anteroposterior (A) and lateral (B) showing a hypoplastic calcaneus.

Featured goals of management were considered, which included prevention of direct pressure and injury to the sole of the heel with improvement in gait pattern. A careful consideration of surgical treatment with 'autologous reconstruction flap surgery' could be achieved with a vascularised myofasciocutaneous flap. This was discussed with the family, including complications such as painful surgical scar, viability of flap and loss of proprioception in the reconstructed heel. They declined surgery. Non-operative management using a custom-made orthosis with well-padded cushion heel 'filler' inserts to improve shock absorption and medial arch support was advised. This is being modified at regular intervals as growth of the foot progresses.

\section{Learning points}

- Congenital aplasia of the heel pad may be easily confused with other common congenital foot abnormalities such as congenital talo equino varus (clubfoot) or congenital vertical talus.

- It can be an unusual and rare cause of limp in adolescence.

- This complex condition is difficult to treat and footwear modifications may alleviate some of the symptoms.

Contributors KPI and GGV were involved in conceptualisation, literature search, manuscript writing and editing. SM and VKJ did the literature search, manuscript writing, references and editing. KPI supervised overall submission and approved the final draft. All authors read and agreed with the final revision of the draft submitted.

Funding The authors have not declared a specific grant for this research from any funding agency in the public, commercial or not-for-profit sectors.

Competing interests None declared.

Patient consent for publication Parental/guardian consent obtained.

Provenance and peer review Not commissioned; externally peer-reviewed.

\section{ORCID iDs}

Karthikeyan P lyengar http://orcid.org/0000-0002-4379-1266

Gopalkrishna G Verma http://orcid.org/0000-0002-9662-7013

\section{REFERENCES}

1 Porat S, Wexler MR. Congenital dysplasia of the heel fat pad: a case report of a previously undescribed entity. Foot Ankle 1991;12:125-9.

2 Keller TS, Weisberger AM, Ray JL, et al. Relationship between vertical ground reaction force and speed during walking, slow jogging, and running. Clin Biomech 1996;11:253-9.

3 Adegbehingbe 00, Asuquo JE, Joseph MO, et al. The heel pad in congenital idiopathic clubfoot: implications of empty heel for clinical severity assessment. Iowa Orthop J 2015;35:169-74.

Copyright 2020 BMJ Publishing Group. All rights reserved. For permission to reuse any of this content visit

https://www.bmj.com/company/products-services/rights-and-licensing/permissions/

BMJ Case Report Fellows may re-use this article for personal use and teaching without any further permission.

Become a Fellow of BMJ Case Reports today and you can:

- Submit as many cases as you like

- Enjoy fast sympathetic peer review and rapid publication of accepted articles

- Access all the published articles

- Re-use any of the published material for personal use and teaching without further permission

\section{Customer Service}

If you have any further queries about your subscription, please contact our customer services team on +44 (0) 2071111105 or via email at support@bmj.com.

Visit casereports.bmj.com for more articles like this and to become a Fellow 